\title{
Microplastics Patch Based on Hydrodynamic Modeling in The North Indramayu, Java Sea
}

\author{
Dannisa Ixora Wanadwiva Handyman ${ }^{1,2}$, Noir Primadona Purba ${ }^{2 *}$, \\ Widodo Setiyo Pranowo ${ }^{3,4}$, Syawaludin Alisyahbana Harahap ${ }^{1}$, \\ Ibnu Faizal Dante ${ }^{1}$, Lintang Permata Sari Yuliadi ${ }^{1}$
}

\author{
${ }^{1}$ Department of Marine Science, Padjadjaran University, West Java, Indonesia \\ ${ }^{2}$ KOMITMEN Research Group, Padjadjaran University, West Java, Indonesia \\ ${ }^{3}$ Marine and Coastal Data Laboratory, Marine Research Center, Indonesian Ministry of Marine Affairs \& Fisheries, \\ Jakarta, Indonesia \\ ${ }^{4}$ Department of Hydrography Engineering, Indonesian Naval Postgraduate School (STTAL), Jakarta, Indonesia
}

Received: 25 August 2017

Accepted: 2 January 2018

\begin{abstract}
Marine debris becomes a global issue due to its impact to ecosystem, human life, and marine environment. Microplastic is one of the marine debris types that need further attention due to its long term effect in marine life. The aim of the study was to investigate the microplastic transport in Java Sea, Indramayu for seven months period. The result showed that the tidal reversing current was dominant in Java Sea, with average current speed $0.04-0.32 \mathrm{~m} / \mathrm{s}$. The type of tidal movement in North Indramayu, Java Sea is mixed tide prevailing semidiurnal. The transport of microplastic has a circular-reversing pattern due to influences from the currents and waves. According to the result of this study, the start point of microplastics could be estimated ranges in distance $0.9-5.4 \mathrm{~km}$ from the location where they were sampled seven months later. Microplastic that currently resides in Java Sea allegedly came from South China Sea and Pacific Ocean. The result also indicates that Java Sea has a high probability to become the largest microplastic patch in Indonesia due to its reversing current, which can trap those particles for a long time (7 months microplastics mileage range of $1258.90 \mathrm{~km}-1399.88 \mathrm{~km}$ ), whether they originate from other ocean region or from Indonesia itself.
\end{abstract}

Keywords: Java Sea, microplastic, hydrodynamic modeling, North Indramayu, tidal current

\section{Introduction}

Marine debris has become a global issue and is regarded as a ubiquitous issue in the world's oceans due

*e-mail: noirpurba@gmail.com to its impact on the global environment, economy, and human health [1-4]. Approximately $60-80 \%$ of global litter consists of plastic [5], and $10 \%$ of them are dumped into the oceans where the degradation process can take several hundred years. The accumulation of floating plastic debris was first observed in North Pacific Gyre, and later the term ocean garbage patch was introduced to describe the accumulation zone of floating debris [6]. 
Approximately more than 21,290 tons of plastic debris has been found accumulated in the subtropical North Pacific Gyre [7]. Until this day, five ocean garbage patches have been identified throughout the world, in the North Atlantic, South Atlantic, South Indian, North Pacific, and South Pacific oceans. The next garbage patch is predicted to emerge in the Barents Sea [8].

Furthermore, the research that was conducted by Jambeck et al. [9] shows that Indonesia is the second biggest source of plastic waste in oceans after China, putting Indonesia under a United Nation spotlight regarding plastic marine debris. Marine debris abundance in Indonesia comes from 2 main sources: ocean currents that link the Pacific to the Indian oceans, and rivers. River pollution is highly indicated as one of the main factors in marine pollution as has been observed in Kuta Beach, Bali [10]. Purba et al. [11] found 3-26 kg accumulated debris along the coastline of Biawak Island, Indramayu, West Java, which is an uninhabited island. This proves that the water complexity also affects the transport and accumulation of floating marine debris.

Mega-sized plastic will undergo a degradation process while floating and then degrades into smaller pieces. The term microplastic is generally used to describe the micro-sized plastic with a grain size lower than $5 \mathrm{~mm}$ [12]. Microplastics have a huge impact on the marine environment due to the bioaccumulation process and their involvement in the marine food chain [13]. The largest microplastics accumulation zone was found in the North Pacific, weighing 93-236 thousand metric tons [14]. Microplastics research in the Java Sea firstly was conducted by Pangestu [15] with $0.2 \mathrm{mg} / \mathrm{L}$ microplastics found in clean Java Sea water. Waters are susceptible to debris accumulation from land, shipping, tourism, and fishery activities. The Java Sea has a high susceptibility on this matter because it borders Java
Island, which is the most-populated island in Indonesia. The Java Sea is also one of the potential fisheries management areas, so microplastics research in this area is necessarily important.

Current is the dominant factor in microplastics transport [16]. Current can be generated by tidal propagation and wind force [17]. Current circulation of Biawak Islands coastal waters in the Java Sea is dominated by tidal forcing [18]. In this research, a comparison of tidal current velocities and wind-forced current velocities is conducted in order to determine the dominant force of microplastics transport in the Java Sea.

In order to fully comprehend microplastics transport in the water area, a modeling approach is required. The approach methods used in this research were hydrodynamic and particle trajectories modeling. This research emphasized determining the start point of microplastic particles seven months before sampling was conducted by reconstructing the distribution of microplastics with particle trajectories scenarios.

\section{Material and Methods}

\section{Study Area}

The study area of this research is the Java Sea that borders Indramayu to the south and Biawak Island to the north $\left(5.9^{\circ} \mathrm{S}-6.4^{\circ} \mathrm{S}\right.$ and $\left.107.98^{\circ} \mathrm{E}-108.5^{\circ} \mathrm{E}\right)$. There were five microplastic sampling sites used in this research: one located in the mouth of a river, three located in open oceans, and one located on the coast of Biawak Island. There were also three hypothetical source scenarios used in this research (Fig. 1).

Bathymetry profile influences the current speed and direction [17]. Bathymetry profile in Java Sea ranges in

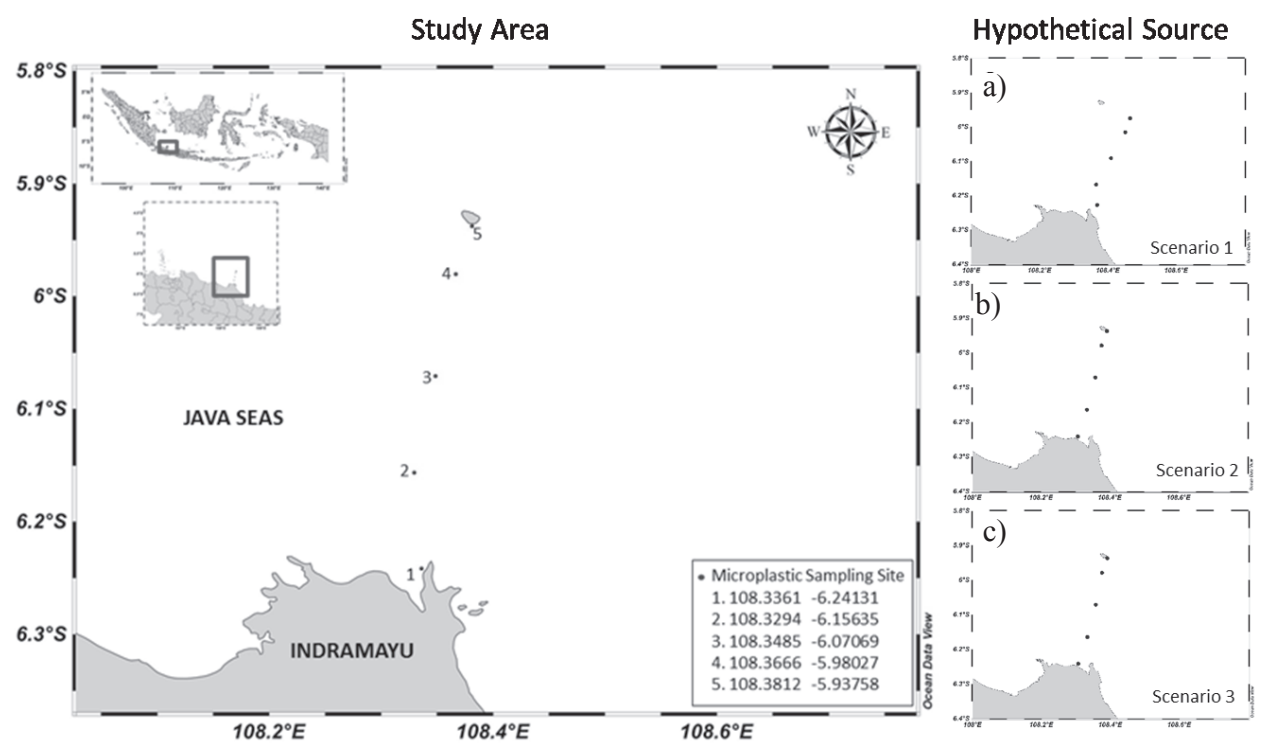

Fig. 1. Study area, with numbers inside the box indicating the sampling sites of microplastics (at left) and hypothetical source scenarios (at right): a) Scenario 1, b) Scenario 2, and c) Scenario 3. 
Table 1. Data and sources.

\begin{tabular}{|c|c|c|c|}
\hline No. & Parameter & Source & Notes \\
\hline 1. & Bathymetry & GEBCO & $\begin{array}{c}\text { General Bathymetric Chart of The Oceans resolution } 1 \mathrm{~km} \\
\text { (www.bodc.ac.uk/data/online_delivery/gebco/) }\end{array}$ \\
\hline 2. & Surface Elevation & TMD, Mike 21 Toolbox & Tidal Model Driver [26] ; Mike by DHI [28] \\
\hline 3. & Wind & ECMWF & $\begin{array}{c}\text { European Centre for Medium-Range Weather Forecasts } \\
\text { (http://apps.ecmwf.int/datasets/) }\end{array}$ \\
\hline 4. & Microplastic Data & Pangestu, et al. [15] & Location, mass, volume, sampling depth : $1 \mathrm{~m}$ \\
\hline
\end{tabular}

depth from 0-50 $\mathrm{m}$ with average depth $40 \mathrm{~m}$ [19]. The water depth region that borders Indramayu coastal waters ranges $4-10 \mathrm{~m}$, while in the open sea it has depth ranges of 20-50 m [15].

The tidal type in Indramayu coastal waters, which bordered with the Java Sea, is mixed tide prevailing semidiurnal, characterized by two uneven tides a day [20]. According to Purba and Harahap [21], surface elevation during monsoon transitional season (March-May) in Biawak Island reached $0.35 \mathrm{~m}$ at the highest tide and $0.34 \mathrm{~m}$ at the lowest ebb. Tidal current circulation in the Java Sea is characterized by its flow, which changes alternately to opposite direction (reversing current) with average current speed $0.04-0.32 \mathrm{~m} / \mathrm{s}$ [22].

The lowest wind velocity during November 2015 to May 2016 occurred in November, at $0.05 \mathrm{~m} / \mathrm{s}$, and the highest velocity occurred in December 2015, at $9.77 \mathrm{~m} / \mathrm{s}$ [23]. The wind velocity increased significantly in early December 2015, which was the start of the west monsoon season (December-February) [24]. During a seven-month period, the wind blew dominantly from west to east [23]. However, there were times that the wind blew from northwest to southeast [17]. The western monsoon season is more dominant in determining wind direction than the transitional season [23].

\section{Datasets}

Data used for hydrodynamic modeling are $\sim 1 \mathrm{~km}$ spatial bathymetry [25], an hourly tidal elevation [26], and six hourly wind-fields [23]. The initial condition data of microplastics was collected by Pangestu [15] in May 2016. The oceanography data, such as wind-fields and surface elevation, used in this research are backward for seven months since sampling, starting from November 2015 until May 2016. The detail of modeling data input is depicted in Table 1.

\section{Hypothetical Source}

The hypothetical source is the term used in this research as the estimated start point of microplastics initial condition [27]. Hypothetical sources need to be simulated in order to estimate the most suitable source of microplastics during a certain period. The determination of hypothetical sources is based on the microplastics sampling site and visualization of hydrodynamic modeling. Afterward, the hypothetical source is used in the particle trajectories scenarios to estimate the microplastic start point seven months before sampling was conducted.

Microplastic flux for all the scenarios is the same, and the start point of microplastics is the only condition that changed in every scenario. In order to acquire a suitable result, three scenarios are used in this research as a hypothetical concept:

1) For the first scenario, hypothetical sources located to the east or west of the sampling site due to the reversing current that causes the particle moves horizontally.

2) For the second scenario, hypothetical sources are located close to the sampling site, and there would

Table 2. Comparison of currents.

\begin{tabular}{|c|c|c|c|c|c|c|c|}
\hline No. & Longitude & Latitude & V1 $(\mathrm{m} / \mathrm{s})$ & $\mathrm{V} 2(\mathrm{~m} / \mathrm{s})$ & $\mathrm{V} 3(\mathrm{~m} / \mathrm{s})$ & $\mathrm{V} 1-\mathrm{V} 3(\mathrm{~m} / \mathrm{s})$ & $\mathrm{V} 2-\mathrm{V} 3(\mathrm{~m} / \mathrm{s})$ \\
\hline 1 & 108.464 & -5.976 & 0.2604 & 0.2593 & 0.2620 & 0.0015 & 0.0026 \\
\hline 2 & 108.409 & -6.092 & 0.2611 & 0.2598 & 0.2633 & 0.0022 & 0.0035 \\
\hline 3 & 108.368 & -6.228 & 0.1621 & 0.1599 & 0.2368 & 0.0746 & 0.0769 \\
\hline 4 & 108.365 & -6.167 & 0.2105 & 0.2100 & 0.2507 & 0.0402 & 0.0407 \\
\hline 5 & 108.368 & -6.226 & 0.1621 & 0.1599 & 0.2493 & 0.0871 & 0.0894 \\
\hline
\end{tabular}

Notes:

1. V1: Tidal current velocities without the influence of wind force

2. V2: Wind-forced current velocities

3. V3: Microplastic velocities 
be an adjustment of distance and angle from the first scenario.

3) For the third scenario, hypothetical sources are located close to the sampling site and there would be an adjustment of distance and angle from the second scenario.

\section{Hydrodynamic and Particle Trajectories}

Modeling

The scenario simulation was conducted using Mike 21 Flow Model FM of Mike 21 [28]. The hydrodynamic and a particle tracking modules are employed in this research [27].

\section{Scenario 1}
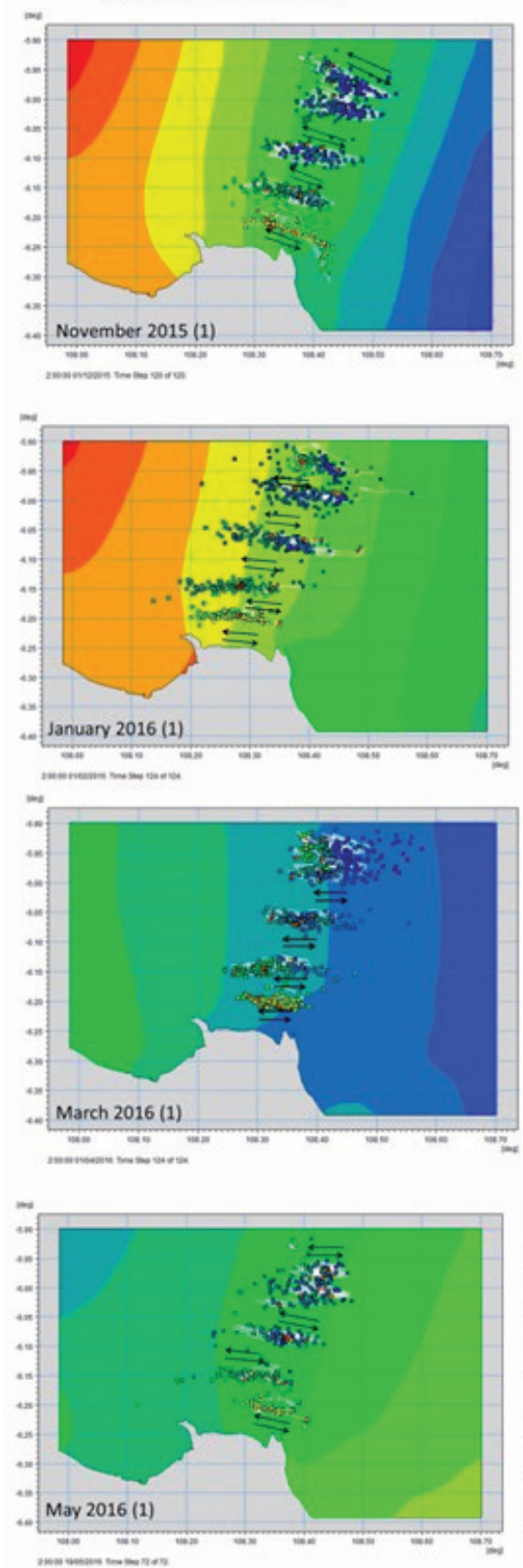

Scenario 2
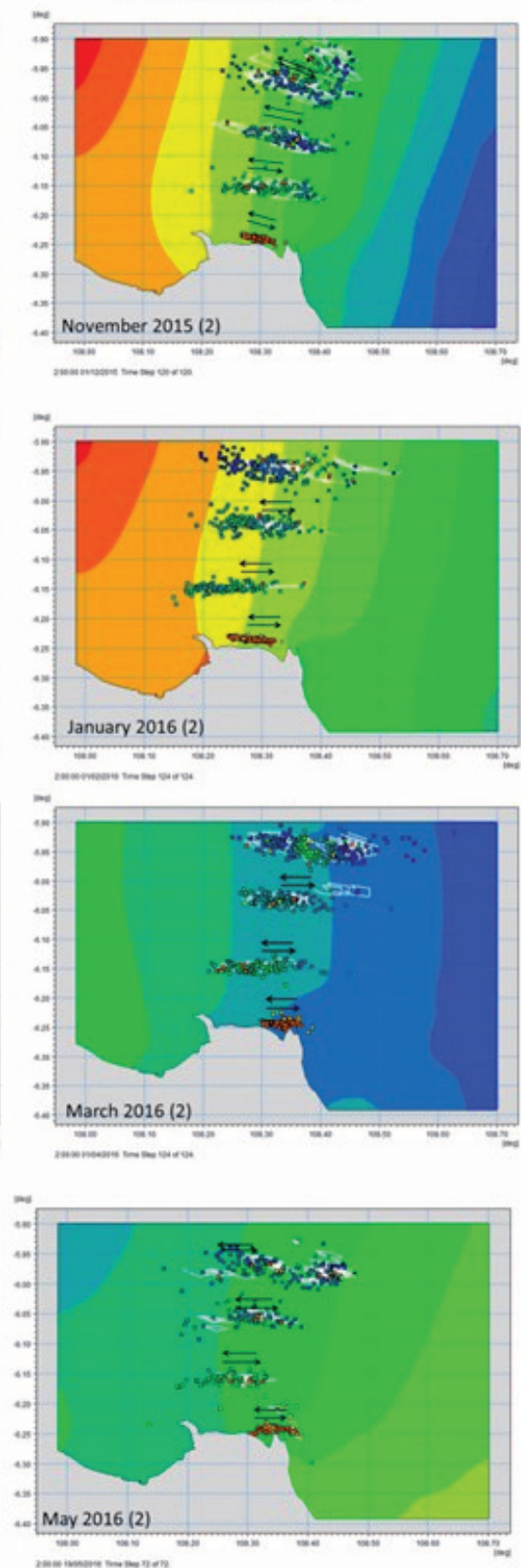

\section{Scenario 3}
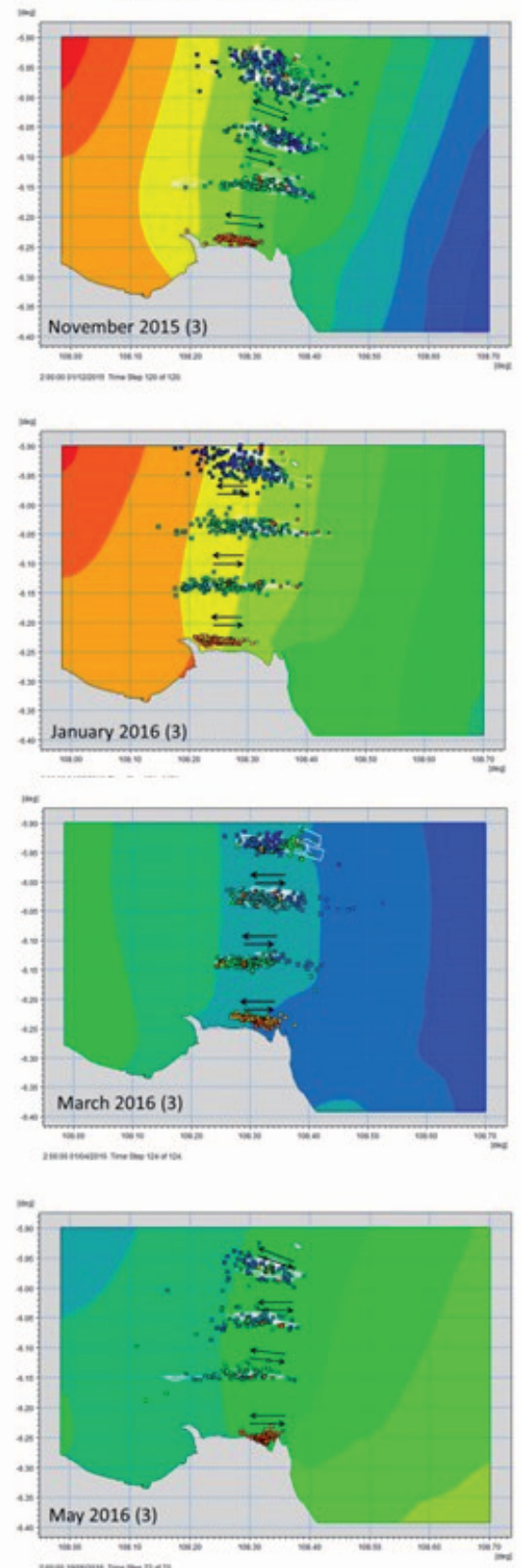

Depth of Microplastic (m)

Surface Elevation $(\mathrm{m})$

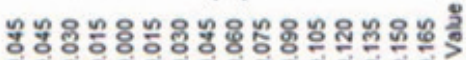

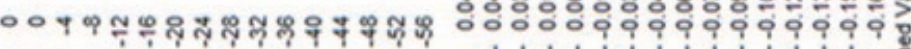

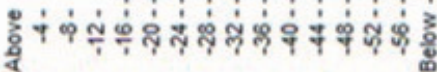

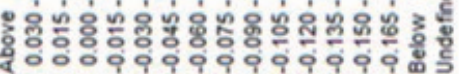
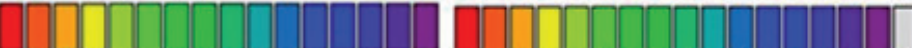

Fig. 2. Particle trajectories simulation results. 
Two-dimensional barotropic hydrodynamic modeling with a depth average was simulated to generate current circulation and the dynamics of sea surface elevation [29]. Particle trajectories simulation is conducted based on three hypothetical source scenarios. The microplastics particles will dynamically be transported by the dominant current circulation [16].

\section{Data Analysis}

A descriptive analysis based on simulation results is conducted in order to derive the characteristics of current circulation, surface elevation propagation, and including microplastics trajectories in North Indramayu, Java Sea [30]. The most suitable hypothetical sources can be determined by the least error values [31]. An error value is measured by the spatial trajectories distance coverage during 7 months of simulation [27]. It is compared to the scenarios simulation and what microplastic are found in North Indramayu, Java Sea [15].

\section{Results and Discussion}

\section{Currents Circulation}

Currents are acquired from surface elevation and wind-fields. The current simulation shows that Indramayu coastal waters have to reverse current type, characterized by the alternate flows from west to east and vice versa. The current velocities range from $0.04-0.28 \mathrm{~m} / \mathrm{s}$ on flood to ebb conditions, $0.2-0.34 \mathrm{~m} / \mathrm{s}$ on ebb condition, $0.04-0.24 \mathrm{~m} / \mathrm{s}$ on ebb to flood conditions, and $0.04-0.18 \mathrm{~m} / \mathrm{s}$ on flood condition. Current velocity is influenced by the range of surface elevation.
Table 3. Hypothetical source with the least error value.

\begin{tabular}{|c|c|c|c|c|}
\hline \multirow{2}{*}{ St } & \multicolumn{2}{|c|}{ HS } & \multirow{2}{*}{$\begin{array}{c}\text { Error } \\
\text { Value }(\mathrm{km})\end{array}$} & \multirow{2}{*}{$\begin{array}{c}\text { HS-TSM } \\
\text { Distance } \\
\quad(\mathrm{km})\end{array}$} \\
\hline & Longitude & Latitude & & \\
\hline 1 & 108.28802 & -6.23824 & 0.46 & 5.34 \\
\hline 2 & 108.33310 & -6.16442 & 1.02 & 1 \\
\hline 3 & 108.35698 & -6.06934 & 1.01 & 0.97 \\
\hline 4 & 108.37880 & -5.98031 & 0.74 & 1.38 \\
\hline
\end{tabular}

\section{Modeling Verification}

The pattern of microplastics transport shows a circular-reversing pattern with approximately a 1-5 $\mathrm{km}$ radius, which corresponds to Chen et al. [32], who states that particle movement has a circular pattern due to influences from wave propagation and wave transformation. A current comparison of tidal current velocities and wind-forced current velocities is depicted in Table 2.

Tidal current is concluded to be more dominant than wind-forced current $(V 1>V 2)$. Microplastics particles can sink to the deeper part of the water, so tidal propagation affects its transport more than wind-forced current $(V 1-V 3<V 2-V 3)$. The wind-forced current has a lower velocity than tidal current [27]. It is allegedly caused by the fluctuation of wind stress toward time because when the wind stops blowing the currents do not automatically stop because there is also momentum caused by some force passed on from one object to another [33].

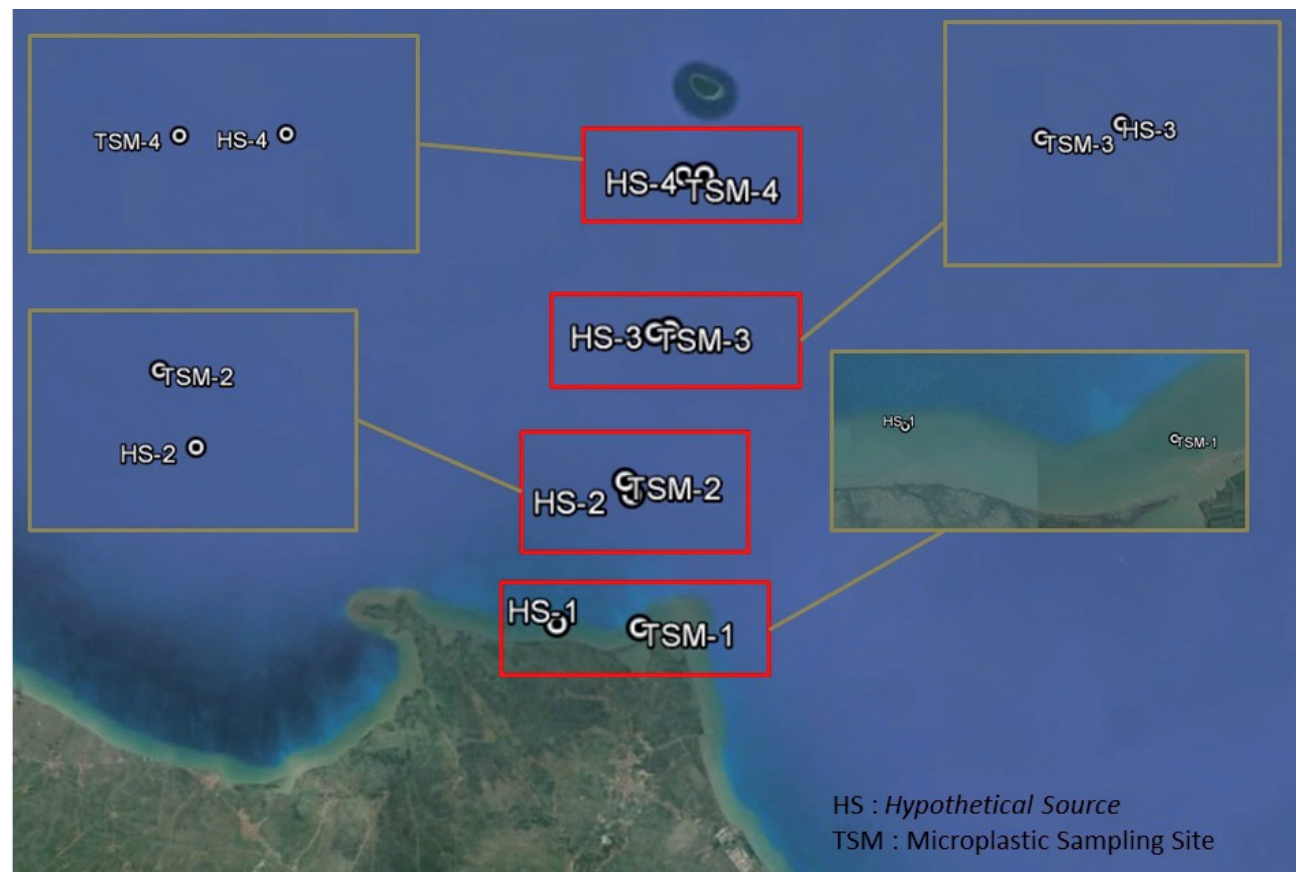

Fig. 3. Visualization of suitable hypothetical sources and microplastic sampling sites. 
Particle trajectories simulation is conducted to prove the start point estimation (Fig. 2). The most suitable hypothetical sources can be determined by comparing error values of each scenario [22]. Table 3 depicts the location of hypothetical sources with the least error value among others (HS-TSM Distance). Fig. 3 shows geographically the most suitable hypothetical sources and microplastic sampling site locations [19].

\section{Microplastic Trajectories}

Particle Trajectories simulation has been successfully conducted based on three different hypothetical sources as scenarios. Figs 1 and 3 show the location of sampling sites and three hypothetical sources scenarios, where the hypothetical sources are not located too far from the sampling site. The decision is based on the reversing current that is dominant and significant in that area so the microplastics particle would move back and forth.

Fig. 2 shows that the microplastics transport in the Java Sea has a circular-reversing pattern with displacement ranges at a distance of from $0.6-9.28 \mathrm{~km}$, the distance varied with the location of each site. Particles that were simulated originate from the shallow waters had greater displacement distance than the particles that originated from deep water [17]. The displacement distance is influenced by bathymetry profile, particle masses, and current velocity [27].

According to Fig. 3, the most suitable hypothetical sources are located not too far from the sampling site, especially stations 2, 3, and 4 located in open water areas [19]. It also can be concluded that the start point of microplastics ranges in distance from 0.9-5.4 km from the sampling sites. Moreover, Pangestu [15] simulated the microplastics transport for five days and showed the similar pattern with seven-month simulations. Table 4 shows the comparison of the microplastic particles approximate mileage for five days [15] and seven months. It shows that the mileage of the seven-month period is approximately 200 times the mileage of five-days simulation, although the particles ended up in the similar places for both circumstances.

Overall, based on Table 4, the simulation results of 7 months microplastics mileage (1258.90-1399.88 km), indicate that the Java Sea has a high potential to become the largest microplastics patch in Indonesia due to its

Table 4. Comparison of microplastic mileage.

\begin{tabular}{|c|c|c|}
\hline Station & $\begin{array}{c}5 \text { Days mileage } \\
(\mathrm{km})[15]\end{array}$ & $\begin{array}{c}7 \text { Months mileage } \\
(\mathrm{km})\end{array}$ \\
\hline 1 & 3.2 & 1392.7 \\
\hline 2 & 5.3 & 1325.1 \\
\hline 3 & 5.5 & 1258.9 \\
\hline 4 & 5.3 & 1332.9 \\
\hline 5 & 5.5 & 1399.9 \\
\hline
\end{tabular}

ability to trap marine debris for a long time [17]. It is scientifically proven that the reversing current has the dominant role in transporting microplastics particles, causing the particles to move circularly within a short radius [27]. The reversing current has great potential to trap the microplastics particles and any other kind of marine debris for a long time. There is a slight chance for those particles to displace to other water regions once they're trapped in the Java Sea due to its reversing current [9].

Preliminary analysis of debris in Biawak Island coastal waters in the Java Sea conducted by Purba et al. indicates that the debris in all the beach is not an endemic debris but transported by ocean currents. It is indicated that all the debris have been transported far from the settlement. The research also shows that debris in Biawak Island coastal waters in Java Sea also come from several sources, e.g., Singapore, Batam, Borneo, and Semarang City [11]. In this case, it could be estimated that the microplastic particles that currently reside in the Java Sea come from other water regions, most likely the South China Sea and the Pacific Ocean, since there are two current systems that connect those waters, which are the Indonesian through-flow and monsoonal Indonesia current [23]. Marine debris can be distributed far away from its source transported by wind and currents [34].

The Java Sea is Indonesian Fisheries Management Area No. 712, so the microplastics accumulation in this area can pose a major threat to the fisheries sector and society in general [22]. Microplastics can be involved in the marine food chain and then eventually accumulated in the high-trophic organisms. The latest research shows that microplastics fragments are found in $25 \%$ of the fish sold in the Indonesia market [35]. The microplasticscontaminated fish would be all over the market if this matter is not taken seriously. Therefore, cooperation and coordination of various parties, such as ministry, institutions, and society, are required to overcome the microplastics issue in the marine environment.

\section{Conclusions}

Current circulation in Indramayu Coastal Waters of the Java Sea is dominantly influenced by reversing tidal current. Microplastics transport has a circularreversing pattern that is also influenced dominantly by tidal propagation. The results of Particle Trajectories simulations with three different hypothetical source scenarios estimated the start point of microplastics, ranging in distance from 0.9-5.4 $\mathrm{km}$ from the sampling site for a seven-month period. The Java Sea has a high potential to be the largest microplastics patch in Indonesia due to the reversing current that can trap debris for a long time (7 months microplastics mileage range of 1258.90-1399.88 km). Microplastics particles that currently reside in the Java Sea allegedly originate from the South China Sea and the Pacific Ocean. 


\section{Acknowledgements}

The authors would like to thank Isnan Fazri Pangestu for his contribution in providing the raw data of microplastic in the Java Sea; the Marine and Coastal Data Laboratory, Marine Research Center (Agency for Marine and Fisheries Research and Human Resources) for providing data, discussion, and facilities during this research; and the crew of the KOMITMEN Research Group for the discussion during data processing. The MIKE 21 Modeling Software of DHI is licensed to Marine Research Center, Agency for Marine Research \& Human Resources, and the Indonesian Ministry of Marine Affairs and Fisheries.

\section{Conflict of Interest}

The authors declare no conflict of interest.

\section{References}

1. SIUNG-CHANG A. A review of marine pollution issues in the Caribbean. Environmental Geochemistry and Health, 19, 45, 1997

2. CHO D.-O. The incentive program for fishermen to collect marine debris in Korea. Marine Pollution Bulletin, 58, 415, 2009.

3. BUTLER J., GUNN R., BERRY H., WAGEY G., HARDESTY B., WILCOX C. A value chain analysis of ghost nets in the Arafura Sea: identifying trans-boundary stakeholders, intervention points, and livelihood trade-offs. Journal of Environmental Management, 123, 14, 2013.

4. THOMPSON R.C., MOORE C.J., VON SAAL F.S., SWAN S.H. Plastics, the environment and human health: current consensus and future trends. Philosophical Transaction of the Royal Society B: Biological Science, 364 (1526), 2153, 2009.

5. DERRAIK J.G.B. The pollution of the marine environment by plastic debris: a review. Marine Pollution Bulletin, 44, $842, \mathbf{2 0 0 2}$

6. MOORE C.J., MOORE S.L., LEECASTER M.K., WEISBERG S.B. A comparison of plastic and plankton in the north Pacific central gyre. Marine Pollution Bulletin, 42 (12), 1297, 2001.

7. LAW K.L., MORET-FERGUSON S., MAXIMENKO N., PROSKUROWSKI G., PEACOCK E.E., HAFNER J., REDDY C.M. Plastic accumulation in the North Atlantic subtropical gyre. Science, 329, 1185, 2001.

8. JAMBECK J., GEYER R., WILCOX C., SIEGLER T. R., PERRYMAN M., ANDRADY A., LAW K.L. Plastic waste inputs from land into the ocean. Science, 347 (6223), 768, 2015.

9. VAN SEBILLE E., ENGLAND M.H., FROYLAND G. Origin, dynamics and evolution of ocean garbage patches from observed surface drifters. Environmental Research Letters, 7, 044040, 2012.

10. ATTAMIMI A., PURBA N.P., ANGGRAINI S.R., HARAHAP S.A. Investigation of Marine Debris in Kuta Beach Bali. In: Suhartanto E., Juwono P.T., WWS, A., Andawayanti U., Hidayat F., Susilo G.E. (eds), Proceedings of Environmental Engineering and Water Technology,
Integrated Water System and Governance (Malang, East Java, Indonesia), pp. C1-7, 2015.

11. PURBA N.P., SYAMSUDIN M.L., SANDRO R., PANGESTU I.F., PRASETIO M.R. Distribution of Marine Debris in Biawak Island, West Java, Indonesia. World Scientific News, 66, 281, 2017.

12. ARTHUR C., BAMFORD H., BAKER J. Proceedings of the International Research Workshop on the Occurrence, Effects, and Fate of Micro-plastic Marine Debris. NOAA Technical Memorandum NOS-OR\&R-30, 530, 2009.

13. FARREL P., NELSON K. Trophic level transfer of microplastic: Mytilus edulis (L.) to Carcinus maenas (L.). Environmental Pollution, 117, 1, 2013.

14. VAN SEBILLE E., WILCOX C., LEBRETON L., MAXIMENKO N., HARDESTY B.D., VAN FRANEKER J.A., LAW K.L. A global inventory of small plastic debris. Environmental Research Letters, 10 (12), 124006, 2015.

15. PANGESTU I.F., PURBA N.P., SYAMSUDIN M.L. Microplastic Condition in Indramayu Waters, West Java. In: Afrianto E., Yustiati A., Hasan Z., Anna Z., Andriani Y., Rizal A., Syamsudin M.L. (Ed.), Proceedings of the National Seminar on Fisheries and Maritime Affairs: Technology, Law and Policy Synergy on Fisheries and Marine Sciences Toward Food Sovereignty in AEC (Bandung, Indonesia), 382, 2016 [In Indonesian].

16. PRANOWO W.S., NINGSIH N.S., SUPANGAT A. Modelling of Nitrogen Compound Distribution in Jepara Waters, Northern Coast of Central Java - Indonesia. Journal of JTM, 12, 2, 2005

17. MUSTIKASARI E., DEWI L.C., HERIATI A., PRANOWO W.S. Three-dimensional Barotropic Current Modeling To Simulate Upwelling Phenomenon in Indonesia Waters. J. Segara, 11 (1), 25, 2015 [In Indonesian].

18. FITRIADI C.A., DHAHIYAT Y., PURBA N.P., HARAHAP S.A., PRIHADI D.J. Coral Larvae Spreading Based On Oceanographic Condition In Biawak Islands, West Java, Indonesia. Biodiversitas, 18 (2), 681, 2017.

19. GOOGLE EARTH. Java Sea $5.9^{\circ} \mathrm{S}, 107.98^{\circ} \mathrm{E}$. Available online: http://www.google.com/earth/index.html (accessed on 21 May 2017).

20. WIDISANTOSA H., PRANOWO W.S., SIMANJUNTAK S.M., SETIADI H. Comparison Study of Tidal Harmonic Component Towards Sea Surface Temperature in Pari Island. J. Chart Datum, 2 (2), 32, 2016 [In Indonesian].

21. PURBA N.P., HARAHAP S.A. Small Islands in Indonesia. The Perspective of a Maritime Biawak-Gosong-Cendikia. Unpad Press: Bandung, Indonesia, 2013 [In Indonesian].

22. PRANOWO W.S., PRAMONO G., HUTOMO M., NONTJI A., MAUFIKOH I. Oceanographic Characteristic of DKI Jakarta Ecoregion, In Dynamics of Jakarta Bay: Prediction Analysis of Development Impact of Jakarta Giant Sea Wall, $1^{\text {st }}$ ed; Poernomo, A., Sulistiyo, B., Wirasantosa, S., Brodjonegoro, I. S., Falashifah, F., Eds., IPB Press: Bogor, Indonesia, ISBN:978-979-493-776-1,96+xxvi, 2013 [In Indonesian].

23. SIREGAR S.N., YULIADI L.P.S., PURBA N.P., PRANOWO W.S., SYAMSUDIN M.L. Water Mass Exchange in Java Sea Towards Monsoon Periodicity and ITF on 2015. Jurnal Ilmu-Ilmu Perairan, Pesisir, dan Perikanan, 6 (1), 2017 [In Indonesian].

24. WICAKSANA S., SOFIAN,I., PRANOWO W.S., KUSWARDANI A.R.T.D., SAROSO SUKOCO N.B. Characteristics of Significant Wave in Karimata Strait and Java Sea Based On Windfields Average for 9 Years (2005-2013). J. Omni-akuatika, 11 (2), 33, 2015 [In Indonesian]. 
25. PRANOWO W.S. Dynamics of Upwelling and Downwelling in Arafura and Timor Sea. J. Widya Riset, 15 (2), 415, 2012 [In Indonesian].

26. EROFEEVA L. Tidal Model Driver. Oregon State University. 2003.

27. PRANOWO W.S., HERDIANI Y., RADJAWANE I.M. Barotropic Tidal and Wind-Driven Larval Transport on Saleh Bay, Sumbawa, Indonesia. APEC/MRC/OMISAR The Twelfth Workshop on Ocean Models (WOM-12) 7-10 September, 2004, Dalian, P. R. China, 12, 2004.

28. MIKE BY DHI. Available online: http://www.mikebydhi. com (accessed on 30 November 2016).

29. RADJAWANE I.M., HERDIANI Y. PRANOWO W.S., HUSRIN S., SUPANGAT A. Vertical Current Circulation in Saleh Sumbawa Bay, West Nusa Tenggara. J. Segara, 2 (1), 206, 2006 [In Indonesian].

30. PRANOWO W.S., ADI R.A., PERMANA H., HANANTO N.D. Surface Current Circulation in Muara Pegah, Delta Mahakam, East Borneo. J. Segara, 8 (1), 56, 2012 [In Indonesian].

31. PRANOWO W.S., KONGKO W. Modelling of the Bengkulu Minor Tsunami Event, September 12, 2007,
West Sumatera, Indonesia: Comparison on Single- and Multi-Segment of Source Generation. J. Segara, 5 (2), 99, 2009.

32. CHEN Y.-Y., LI M.-S., SHU H.-C., NG C.-O. Theoretical and experimental study of particle trajectories for nonlinear water waves propagating on a sloping bottom. Philosophical Transactions of The Royal Society, 370, 1543, 2012.

33. PURBA N.P., PRANOWO W.S. Dynamics of Oceanography Description of Watter Mass Characteristic and Sea Circulation. Unpad Press: Bandung, Indonesia, 2015 [In Indonesian].

34. NATIONAL OCEANIC AND ATMOSPHERIC ADMINISTRATION (NOAA). Programmatic Environmental Assessment (PEA) for the NOAA Marine Debris Program (MDP). Maryland, US: NOAA. 168, 2013.

35. ROCHMAN C.M., TAHIR A., WILLIAMS S.L., BAXA D.V., LAM R., MILLER J.T., TEH F., WERORILANGI S., TEH S.J. Anthrophogenic debris in seafood: Plastic debris and fibers from textiles in fish and bivalves sold for human consumption. Scientific Reports, 5 (14340), 2013. 